\title{
STUDI PENGUASAAN MATEMATIKA DAN BAHASA INGGRIS MAHASISWA PROGRAM STUDI PENDIDIKAN GURU SEKOLAH DASAR (PGSD)
}

\author{
Wahyu Pramudita \\ wahyupramudita@gmail.com \\ Universitas Katolik Indonesia Atma Jaya \\ Indri Anugraheni \\ Indri.anugraheni@staff.uksw.edu \\ Universitas Kristen Satya Wacana Salatiga \\ ABSTRACT \\ Mastery Study Of Math And English \\ Students Of Primary Teachers Education (Pgsd) Program
}

This research was a descriptive non-experimental (field study) that attempted to describe the level of students' mastery on the primary teachers education's student of Atma Jaya Catholic University, specifically the cognitive aspects of basic mathematic and English language referred to curriculum of 2008. This study aimed to 1) mapping of the students' mastery of mathematics and its relevancy, 2) mapping of the students' mastery of English Language and its relevancy. The respondents of this study were 56 students of 2010-2012 batches. The results of this study indicated that the mathematical ability of students was considered good and the English language ability was sufficient.

Keywords: Mathematic Mastery, English Language Mastery, Elementary Teacher Education

\section{PENDAHULUAN}

Salah satu bekal utama yang menjadi dasar pemikiran kritis bagi mahasiswa PGSD adalah kemampuan akademik terkait penguasaan bidang studi ilmu pendidikan di SD. Salah satu contoh penguasaan bidang studi keilmuan dan ilmu pendukungnya adalah matematika dan Bahasa Inggris. Kedua rumpun mata kuliah yang berbeda ini cenderung mendapat perhatian yang serius di kalangan pendidik dikarenakan sifat keilmuannya yang dipandang sulit/tidak mudah dipahami oleh mahasiswa. Russefendi (1988) menegaskan bahwa matematika dapat didefinisikan sebagai suatu ilmu yang terorganisasikan dari definisi-definisi, aksioma-aksioma, dan dalil-dalil yang setelah dibuktikan kebenarannya berlaku secara umum. Sedangkan Bahasa Inggris sebagai ilmu penunjang berperan memberikan sumbangsih pengetahuan dalam bentuk referensi pengembangan keilmuan dengan membiasakan mahasiswa untuk mampu memanfaatkan sumber-sumber mutakhir yang bersumber dari Bahasa Inggris (Depdiknas, 2002).

Mengacu pada pemikiran Ernest (1991) bahwa matematika merupakan sederetan simbolsimbol yang tidak mempunyai makna dan simbol-simbol matematika tidak mewakili hal-hal yang merupakan maknanya tanpa pemahaman bahasa yang melengkapinya, "mathematics is a motley, a 
collection of language games, and that the notion of truth, falsity and proof depend up on our accepting the conventional linguistic rules of these games". Menggarisbawahi pemahaman ini, suatu sistem logis matematis adalah suatu tata permainan bahasa. Suatu permainan akan berjalan dengan lancar jika dipahami aturan permaian yang mendasarinya atau akan terjadi "chaos" jika sistem komunikasi ini berubah tidak sesuai alur yang semestinya. Pemahaman logis matematis memiliki korelasi positif dengan konstruksi sosial bahasa. Suyitno (2008) menekankan bahwa matematika sebagai tata permainan bahasa memiliki aturan dalam artian "grammar". Konsepsi matematika memperhatikan sistem dari sesuatu yang merepresentasikanya, yang pada akhirnya mampu untuk dideskripsikan.

Di satu sisi, Bahasa Inggris merupakan suatu sistem kebahasaan yang muncul tidak dalam koleksi kata-kata yang tidak beraturan melainkan terikat menjadi suatu sistem kesatuan aturan atau prinsip "ruled governed system". Sistem ini terdiri dari unit terkecil yang memiliki fungsi khusus dan saling berelasi satu dengan lainnya, didasari dengan pemikiran logika sosial yang sistemik dan matematik. Sebagai contoh dalam lingkup syntax; aturan dalam bahasa inggris menerima bentuk kalimat "I drink a glass of water or a glass of water I drink", tetapi kurang dapat menerima bentuk kalimat "Drink a glass of water $I$ '. Proposisi dari penyusunan bahasa menunjukkan struktur logis dari bahasa yang membawa makna. Pemikiran logis matematis, esensinya, memberikan kontribusi dominan dalam memberikan makna proposisi. Wittgenstein (1951) menekankan pemahaman ini, "Logic, it may be said, shews us what we understand by proposition and by language"

Menarik benang merah dari pemikiran di atas, pemahaman logis matematis memiliki peranan mendasar dalam memahami konsep kebahasaan dan setiap simbol yang benar harus dapat diimplikasikan ke dalam konsep yang lain secara benar atau sebaliknya. Perbedaan penafsiran dalam memahami konsep akan berdampak pada perbedaan implikasi yang senyatanya. Hal ini menunjukkan bahwa konsep matematis tanpa konsep bahasa yang benar tidak dapat merepresentasikan sistem matematik yang diterima secara umum.

Matematika merupakan salah satu cabang ilmu yang menerapkan logika dalam proses berfikirnya. Sebagai suatu ilmu yang bersifat simbolis, matematika tidak akan bermanfaat tanpa logika berfikir yang benar. Logika yang diasah dalam ilmu matematika merupakan pintu gerbang segala ilmu. Logika menawarkan penalaran logis dalam menguji suatu fenomena/persoalan. Disisi lain, Bahasa Inggris merupakan Bahasa universal yang dominan digunakan dalam bidang keilmuan. Dengan kemampuan Bahasa Inggris yang mencukupi maka aksesibilitas keilmuan menjadi terbuka. Kedua ilmu ini, pada dasarnya semakin melengkapi, sangat berpengaruh terhadap pengembangan keilmuan sehingga jika kedua ilmu ini dikuasai dengan baik akan menjadi dasar yang kuat terhadap pengembangan keilmuan yang lain/IPTEK.

Dalam rangka meningkatkan pengembangan keilmuan secara holistik, maka penulis berusaha melakukan pemetaan terkait kedua ilmu ini sehingga kemampuan dasar mahasiswa dalam upaya memahami bidang keilmuan lainnya dapat semakin ditingkatkan.

\section{KAJIAN PUSTAKA}

Pembelajaran merupakan suatu proses terjadinya interaksi belajar dan mengajar dalam suatu kondisi tertentu yang melibatkan beberapa unsur, baik unsur ekstrinsik maupun intrinsik yang melekat pada diri siswa dan guru termasuk lingkungan. Dimyanti dalam Susanto (2013) menyatakan bahwa pembelajaran adalah kegiatan guru secara terprogram dalam desain instruksional, untuk membuat siswa belajar secara aktif, yang menekankan pada penyediaan sumberdaya. Susanto juga menambahkan bahwa pembelajaran adalah aktivitas guru dalam merancang bahan pengajaran agar proses pembelajaran dapat berlangsung secara efektif, yakni siswa dapat belajar secara aktif dan 
Stusi Penguasaan Matematika dan Bahasa Inggris Mahasiswa Program Studi Pendidikan Guru

Sekolah Dasar (PGSD) (Wahyu Pramudita, Indri Anugraheni)

bermakna. Berdasarkan beberapa pendapat diatas maka dapat disimpulkan bahwa pembelajaran adalah suatu aktivitas guru dalam merancang pembelaj aran yang mampu mengaktifkan siswa selama proses pembelajaran.

Proses pembelajaran di kelas sebagai implementasi dari sebuah kurikulum merupakan sarana untuk membantu siswa memperoleh informasi,ide, keterampilan, nilai, cara berfikir, mengekspresikan diri, dan cara-cara bagaimana untuk belajar. Menurut Suyono\&Hariyanto (2012), pembelajaran dipandang sebagai suatu sistem yang terdiri dari komponen-komponen yang saling bergantung satu sama lain, dan terorganisir antara kompetensi yang harus diraih siswa, materi pelajaran, pokok bahasan, metode dan pendekatan pengajaran, media pengajaran, sumber belajar, pengorganisasian 'kelas, dan penilaian. Pembelajaran dapat berarti suatu proses yang digunakan untuk mengarahkan siswa pada kondisi yang membantu mereka mencapai target belajar. Guru sebagai fasilitator harus mampu mengorganisir semua unsure pembelajaran dan mengarahkannya pada suasana yang memungkinkan seorang siswa untuk belajar, sehingga kompetensi yang diharapkan dapat dicapai.

\section{Pembelajaran Matematika di PGSD}

Matematika adalah hasil pemikiran, yang menunjukkan keutuhan kapasitas pikiran dalam menemukan urutan dan pola peristiwa di dunia, untuk menjelaskan dan memberi arti intelektual tentang dunia, dan untuk menikmati tantangan dan pemecahan masalah yang dimunculkan oleh dirinya sendiri (Mack J, 1994: 264-267). Matematika di sekolah terus berkembang, namun masih sering disajikan sebagai bagian dari pengetahuan semata, bukan sebagai cara untuk memperoleh pengertian. Karena itu, banyak murid memandang matematika sebagai hal yang objektif, tidak fleksibel, datar dan edukatif, terlepas dari budaya, terpisah dari realitas dan merupakan kebenaran mutlak. Namun, para ahli yang profesional sepakat bahwa matematika merupakan produk dari proses yang intuitif dan kreatif, yang mencerminkan kondisi serta perkembangan historis dan sosial, dan aplikasinya menyajikan model - model realitas, daripada kebenaran universal. Matematika sering dianggap sebagai suatu kumpulan sistem matematika yang setiap sistem itu mempunyai strukturstruktur tersendiri yang bersifat deduktif (Hudoyo,1988: 95).

Suatu sistem deduktif dimulai dari unsur yang tidak didefenisikan yang disebut unsur primitif. Unsur tersebut diperlukan sebagai dasar komunikasi selanjutnya ditentukan aksioma - aksioma yang merupakan asumsi - asumsi dasar tertentu. Aksioma tersebut merupakan pemyataan yang menyatakan hubungan dasar dalam unsur-unsur pokok dalam suatu sistem tersebut, dan akhimya diperoleh teorema - teorema yang dibuktikan dengan serentetan pemyataan. Setiap pernyataan dapat berupa defenisi, aksioma atau teorema - teorema dibuktikan kebenarannya. Carter (2007: 74) mendefenisikan matematika adalah sebagai berikut: Mathematics is the manipulation of abstract symbols according to spesific as rules. As such mathematics is a language, but it differs from other languages in its universal nature and its applicability to human endeavors. Mathematics is the objective science of pure reason. Some might say that this ability to reason'mathematically is a characteristic will be the first language of communication between us and other sentient beings when such communications occur. Artinya matematika adalah proses memanipulasi simbol-simbol abstrak sesuai dengan aturan yang khusus. Karena matematika adalah bahasa, tetapi berbeda dengan bahasa yang alami dan penerapan usaha manusia. Matematika adalah objek tujuan. Beberapa pendapat mengatakan bahwa ini kemampuan untuk alasanmatematis adalah karakteristik yang akan menjadi bahasa pertama komunikasi antara kita dan makhluk hidup lainnya ketika komunikasi tersebut tte adi.

Menurut Uno (2009: 130), belajar matematika adalah suatu aktivitas mental untuk memahami arti dan hubungan-hubungan serta simbol—simbol, kemudian diterapkannya dalam situasi nyata. 
Schoenfeld (Uno, 2009: 130) mendefinisikan bahwa belajar matematika berkaitan dengan apa dan bagaimana menggunakannya dalam membuat keputusan untuk memecahkan masalah.

Menurut Hudoyo (1988: 6) pembelajaran adalah suatu proses interaksi dua arah antara pengajar dan mahasiswa. Dapat dikatakan pembelaj aran nlerupakan dua kegiatan yang saling mempengaruhi yang dapat menentukan hasil belajar. Kemudiaan Hudoyo menjelaskan bahwa pembelajaran sebagai suatu rangkaian kejadian atau (events) yang mempengaruhi pembelajar sehingga proses belajarnya dapat berlangsung dengan mudah. Pembelajaran bukan hanya terbatas pada yang diajarkan oleh guru saja, akan tetapi mencakup semua kejadian kehidupan yang mungkin mempunyai pengaruh langsung pada proses belajar manusia. Pembelajaran mencakup kejadiankejadian yang diturunkan oleh bahan-bahan cetak, gambar, program, televisi, film maupun kombinasi dari bahan-bahan tersebut. Dengan demikian fungsi pembelajaran bukan hanya fungsi guru/pengajar, melainkan juga fungsi sumber - sumber belajar lain yang digunakan oleh pembelajar untuk belajar sendiri.

\section{Pembelajaran Bahasa Inggris di PGSD}

Pendidikan guru sekolah dasar sebagai bentuk pendidikan sekolah yang mencetak calon guru $\mathrm{SD}$, seyogyanya memberikan bekal kemampuan dan keterampilan bagi mahasiswa, untuk melandasi pola pikir mereka. Dengan mengambil satu aspek pembelajaran, aspek pembelajaran bahasa, diharapkan bekal yang kuat dalam aspek ini mampu membekali mahasiswa dengan kemampuan unjuk kerja (performance), fungsi (functional), informasi (informative), dan epistemik (epistemic). Pada tahapan unjuk kerja mahasiswa diharapkan mampu berkomunikasi menggunakan simbol melalui membaca, menulis, mendengarkan, dan berbicara. Pada tahapan fungsi, mahasiswa diharapkan mampu menggunakan bahasa untuk memenuhi kebutuhan sehari-hari seperti membaca koran, membaca petunjuk, atau prosedur sesuatu. Pada tahapan informasi, mahasiswa diharapkan mampu mengakses pengetahuan menggunakan kemampuan bahasa mereka sedangkan tahapan epistemik mahasiswa diharapkan mampu mengekspresikan pengetahuan mereka ke bahasa yang dituju (Wells, 1987 as cited in SBC, 2006).

Pada kenyataannya, proses pengajaran dan pembelajaran Bahasa Inggris untuk jenjang sekolah dasar ditujukan sebagai muatan institusional. Dengan persepsi ini, walaupun tidak bersifat wajib, setiap institusi sekolah diharapkan mampu mempersiapkan, dengan melihat konteks sekolah masing-masing, dengan optimal untuk ke jenjang lanjutan tingkat pertama. Dengan berpedoman pada pemikiran ini, standar kompetensi guru kelas/sosok utuh guru kelas SD/MI, menggarisbawahi rumpun kompetensi untuk kemampuan mengembangkan kemampuan profesional secara berkelanjutan dengan penekanan kompetensi untuk kemampuan menggunakan Bahasa Inggris untuk mengembangkan wawasan. Dengan rancangan kompetensi ini, pengalaman belajar Bahasa Inggris di PGSD berkenaan dengan beberapa hal ini (1) Berlatih mengembangkan keterampilan berbahasa Inggris dan (2) Berlatih memanfaatkan berbagai sumber dalam Bahasa Inggris untuk berbagai keperluan. Lingkup pembelajaran Bahasa Inggris ini kemudian dikembangkan, sesuai dengan konteks, untuk membekali mahasiswa pada jenjang selanjutanya dalam kemampuan untuk berkomunikasi pasif yang berfokus pada konteks lingkungan sekolah. Pada tahapan ini, keterampilan menulis dan membaca dikembangkan untuk mendukung kemampuan mahasiswa dalam mengakses ilmu/referensi dan memproduksi tesk tulis sederhana sebagai sarana berkomunikasi.

\section{METODE}

Penelitian ini diawali dengan proses pengamatan situasi/kondisi sosial/institusional kemudian mengkaji sikap, persepsi, dan perilaku individu serta kelompok dalam situasi ini. Penelitian ini 
Stusi Penguasaan Matematika dan Bahasa Inggris Mahasiswa Program Studi Pendidikan Guru Sekolah Dasar (PGSD) (Wahyu Pramudita, Indri Anugraheni)

merupakan penelitian deskriptif yang berusaha untuk mengungkapkan suatu masalah/keadaan sebagaimana adanya. Penelitian ini menekankan pada gambaran objektif suatu kondisi tertentu dengan harapan reflektif untuk manfaat yang lebih luas. Dalam penelitian ini, hal yang akan dideskripsikan adalah gambaran dan tingkat pemahaman mahasiswa terkait mata kuliah matematika dan bahasa inggris.

Subjek penelitian ini adalah mahasiswa Pendidikan Guru Sekolah Dasar (PGSD) Unika Atmajaya. Penelitian ini merupakan penelitian deskriptif yang mencoba mendiskripsikan tingkat penguasaan mahasiswa, khususnya aspek kognitif terkait dengan kemampuan bidang studi. Variabel yang mencoba untuk dianalisis dalam penelitian ini yaitu tingkat pemahaman mahasiswa yang meliputi rumpun matematika (matematika dasar, konsep dasar matematika SD, pembelajaran matematika SD) dan rumpun bahasa inggris (bahasa inggris I, bahasa inggris II).

Teknik pengumpulan data dengan menggunakan Kuesioner. Pertama-tama peneliti membuat kisi-kisi kuesioner. Kisi-kisi kuesioner berdasarkan kompetensi-kompetensi dari mata kuliah matematika dan Bahasa Inggris. Peneliti menentukan kompetensi-kompetensi yang akan diukur, kemudian peneliti membuat indikator-indikator yang akan diteliti. Kisi-kisi yang dibuat, digunakan peneliti untuk membuat lembar kuesioner. Sebelum instrumen digunakan, peneliti melakukan uji validasi isi (content validity). Validasi isi adalah instrumen yang dibuat didasarkan pada kompetensikompetensi yang akan diukur.

Uji validitas dilakukan bertujuan untuk menguji apakah butir tersebut sudah valid untuk mengukur indikatornya. Uji validitas ini dengan menggunakan bantuan program SPSS (Statistic Product Service Solution) versi 17.00 forwindow. Uji validitas bertujuan untuk memastikan bahwa Pernyataan-pernyataan dalam masing-masing variabel dapat terklarifikasi pada variabel-variabel yang telah ditentukan. Dalam penelitian ini peneliti menggunakan cara bivariate pearson. Dimana dalam pengujian ini dengan melakukan korelasi bivariate antara masing-masing skor itemdengan total skor item. Dimana nilai dari korelasi tersebut dibandingkan dengan nilai tabel $\alpha=5 \%$, $\mathrm{df}=\mathrm{n}-2$, dimana $\mathrm{n}$ menunjukkan total data yang digunakan. Maka dalampenelitian ini n yang digunakan sebesar 56, maka nilai $d f$ sebesar 54 dengan tingkat signifikansi sebesar 0.05 maka diperoleh $\mathrm{r}$ table $=0,263$. Hasil dari $r$ table $=0,263$ kemudian dibandingkan dengan $r$ hitung dari hasil penggujian dengan menggunakan korelasi bivariate. Jika $r$ hitung $>r$ table maka item tersebut dinyatakan valid, tetapi jika $r$ hitung $<\mathrm{r}$ table maka item tersebut dinyatakan tidak valid. Hasil validasi dari 38 item menunjukan semua item valid, sehingga 38 pertanyaan dalam kuesioner dapat digunakan sebagai instrument penelitian.

Uji reliabilitas bertujuan untuk mengetahui sejauh mana pengukuran yang telah dilakukan dalam penelitian ini dapat dipercaya atau dapat diandalkan. Konsistensi pengukuran menggambarkan bahwa instrumen tersebut dapat bekerja dengan baik pada waktu dan situasi yang berbeda. Uji reliabilitas dilakukan dengan menghitung nilai Cronbach's Alpha dari masing-masing instrumen dalam suatu variabel. Nilai untuk menentukan reliabilitas suatu instrumen adalah nilai Cronbach's Alpha $>0,8$ maka dikatakan bahwa instrument tersebut reliable (handal). Hasil dari pengolahan data yang dilakukan oleh peneliti dalam penelitian ini akan disajikan dalam tabel berikut ini.

Tabel 1. Reliability Statistics

\begin{tabular}{ll}
\hline Cronbach's Alpha & N of Items \\
\hline .951 & 38 \\
\hline
\end{tabular}


Dari table 3 diatas menunjukkan bahwa cronbach's alpha untuk uji validitas instrumen sebesar 0, 951 dengan nilai $\mathrm{N}=38$. Nilai cronbach"s alpha> 0,80 maka instrumen untuk mengukur penguasaan matematika dan Bahasa Inggris reliabel, sehingga instrument tersebut dapat digunakan.

\section{HASIL DAN PEMBAHASAN}

Jika mengacu pada kurikulum perguruan tinggi, pembelajaran Bahasa Inggris diadakan dengan tujuan untuk meningkatkan kualitas dan luaran yang memiliki daya saing lokal, regional, maupun internasional.

Di satu sisi, pembelajaran matematika merupakan ilmu pembelajaran yang mempunyai peranan penting dalam dunia ilmu pengetahuan. Korelasi antara matematika dan Bahasa Inggris dengan cabang ilmu lain sangat dekat, baik secara langsung maupun tidak langsung. Hal ini sejalan dengan penelitian Khoirunisa (2012) terhadap salah satu Sekolah Menengah Atas Negeri di wates. Hasil penelitian ini menunjukkan bahwa terdapat pengaruh positif antara kemampuan pemahaman istilah Bahasa inggris dan operasi dasar Matematika terhadap kemampuan belajar Teknologi Informasi dan Komunikasi. Hal ini ditunjukkan dengan koefisien korelasi $r$ hitung sebesar 0,491 yang di konsultasikan dengan $r$ tabel 0,195 dengan $\mathrm{N}=119$ dan taraf signifikansi 5\%. Dimana $r$ hitung $>r$ tabel. Sedangkan harga koefisien determinasi ( R2) sebesar 0,241 atau sebesar 24,1\% dan ditunjukkan dengan persamaan $\mathrm{Y}=0,295 \mathrm{X} 1+0,139 \mathrm{X} 2+70,367$.

Gambaran mengenai kedua bidang ilmu ini menjadi penting karena dapat digunakan sebagai pijakan penyusuan metode, teknik, dan pendekatan dalam mencapai hasil optimal dalam pembelajaran. Gambaran penguasaan kedua bidang ilmu, dalam penelitian ini, dibagi menjadi 2 kategori yaitu hasil penguasaan matematika mahasiswa PGSD dan hasil penguasaan Bahasa Inggris mahasiswa PGSD dengan menggunakan kurikulum 2008.

\section{Hasil Penguasaan matematika}

Hasil penguasaan matematika mahasiswa PGSD dibagi dalam 6 indikator. Berikut adalah hasil masing-masing indikator tersebut:

Tabel 2. Persentase penguasaan pengetahuan konseptual dan prosedural serta keterkaitan dalam bidang aritmatika, aljabar, geometri, trigonometri, pengukuran, statistika dan logika matematika

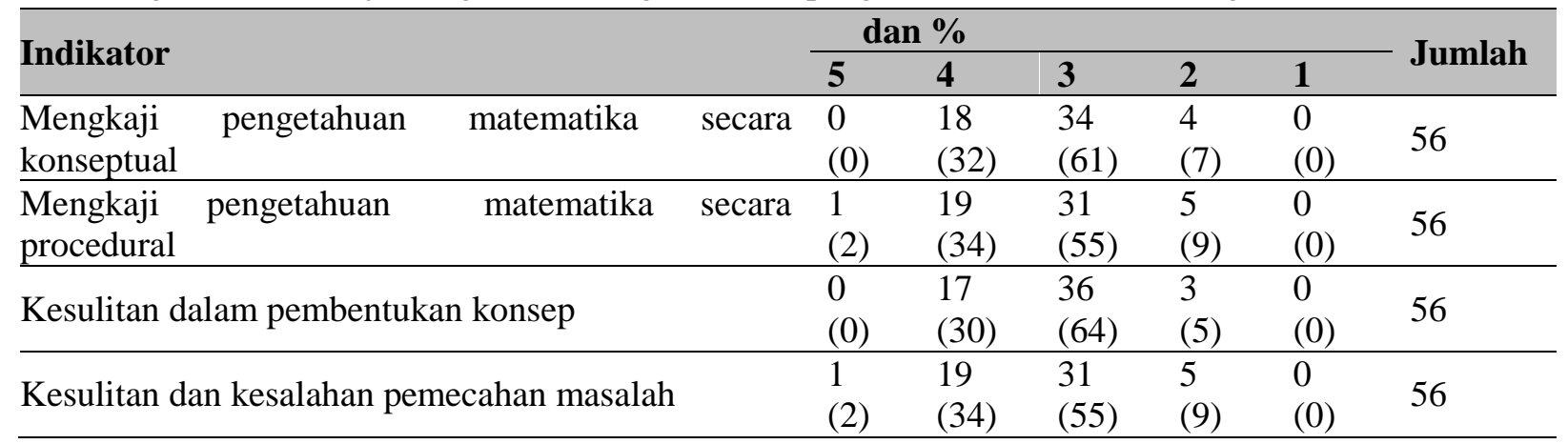

Dari tabel 2 menunjukan bahwa rata-rata mahasiswa PGSD pada aspek penguasaan pengetahuan konseptual dan prosedural serta keterkaitan keduanya dalam bidang aritmatika, aljabar, geometri, trigonometri, pengukuran, statistika dan logika matematika berada pada kemampuan cukup tinggi. Hal ini tampak dari rata-rata pengetahuan matematika secara konseptual berada pada kategori tinggi dengan persentase $32 \%$. Persentase pengetahuan matematika mahasiswa secara procedural berada pada kategori cukup sebesar 55\%. Berdasarkan tabel 2 menunjukkan bahwa 64\% mahasiswa PGSD mengalami kesulitan dalam pembentukan konsep dan 55\% mahasiswa mengalami kesulitan dan kesalahan dalam pemecahan masalah. 
Stusi Penguasaan Matematika dan Bahasa Inggris Mahasiswa Program Studi Pendidikan Guru Sekolah Dasar (PGSD) (Wahyu Pramudita, Indri Anugraheni)

Tabel 3. Persentase matematisasi horizontal dan vertikal untuk menyelesaikan masalah

\begin{tabular}{|c|c|c|c|c|c|c|}
\hline \multirow{2}{*}{ Indikator } & \multicolumn{5}{|c|}{$\sum$ dan \% } & \multirow{2}{*}{ Jumlah } \\
\hline & 5 & 4 & 3 & 2 & 1 & \\
\hline $\begin{array}{l}\text { Logis, kritis, sistematis dalam mengembangkan } \\
\text { pembelajaran }\end{array}$ & $\begin{array}{l}3 \\
(5)\end{array}$ & $\begin{array}{l}23 \\
(41)\end{array}$ & $\begin{array}{l}27 \\
(48)\end{array}$ & $\begin{array}{l}3 \\
(5)\end{array}$ & $\begin{array}{l}0 \\
(0)\end{array}$ & 56 \\
\hline Menerapkan pemikiran inovatif & $\begin{array}{l}3 \\
(5)\end{array}$ & $\begin{array}{l}24 \\
(43)\end{array}$ & $\begin{array}{l}24 \\
(43)\end{array}$ & $\begin{array}{l}5 \\
(9)\end{array}$ & $\begin{array}{ll}0 \\
(0)\end{array}$ & 56 \\
\hline Menerapkan pemikiran implementatif & $\begin{array}{l}1 \\
(2)\end{array}$ & $\begin{array}{l}22 \\
(39)\end{array}$ & $\begin{array}{l}30 \\
(54)\end{array}$ & $\begin{array}{l}3 \\
(5)\end{array}$ & $\begin{array}{l}0 \\
(0)\end{array}$ & 56 \\
\hline
\end{tabular}

Berdasarkan tabel 3 diatas menunjukkan bahwa penguasaan pengetahuan menggunakan matematisasi horizontal dan vertical untuk menyelesaikan masalah berada pada kategori cukup tinggi. Hal ini tampak dari hasil persentase pemikiran logis, kritis, sistematis dalam mengembangkan pembelajaran sebesar $48 \%$ pada kategori cukup tinggi. Persentase mahasiswa dalam menerapkan pemikiran inovatif sebesar $43 \%$ berada pada kategori tinggi. Sedangkan persentase mahasiswa dalam menerapkan pemikiran implementatif sebesar 54\% pada kategori cukup tinggi.

Tabel 4. Persentase pengetahuan konseptual dan prosedural dalam masalah matematika dan penerapannya

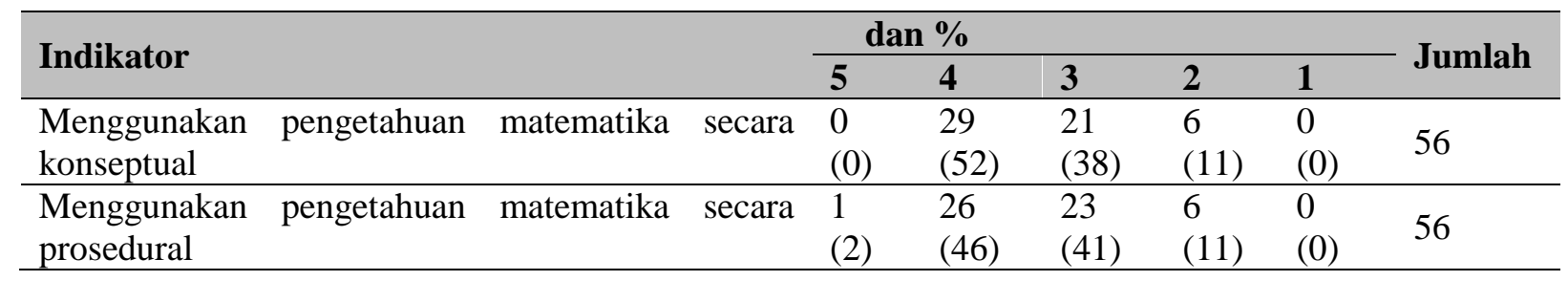

Berdasarkan tabel 4 menunjukkan bahwa penguasaan pengetahuan konseptual dan prosedural serta keterkaitan keduanya dalam pemecahan masalah matematika dan penerapannya berada pada kategori tinggi. Hal ini ditunjukan dari hasil persentase mahasiswa dalam menggunakan pengetahuan matematika secara konseptual sebesar 52\% berada pada kategori tinggi. Sedangkan persentase mahasiswa dalam menggunakan pengetahuan matematika secara procedural sebesar $46 \%$ berada pada kategori tinggi.

Tabel 5. Mengkaji penalaran deduktif dan penalaran induktif

\begin{tabular}{|c|c|c|c|c|c|c|}
\hline \multirow[b]{2}{*}{ Indikator } & \multicolumn{5}{|c|}{$\sum$ dan \% } & \multirow[b]{2}{*}{ Jumlah } \\
\hline & 5 & 4 & 3 & 2 & 1 & \\
\hline Menunjukkan komitmen & $\begin{array}{l}1 \\
(2)\end{array}$ & $\begin{array}{l}33 \\
(59)\end{array}$ & $\begin{array}{l}19 \\
(34)\end{array}$ & $\begin{array}{l}3 \\
(5)\end{array}$ & $\begin{array}{l}0 \\
(0)\end{array}$ & 56 \\
\hline Menunjukkan sikap bertanggung jawab & $\begin{array}{l}2 \\
(4)\end{array}$ & $\begin{array}{l}34 \\
(61)\end{array}$ & $\begin{array}{l}17 \\
(30)\end{array}$ & $\begin{array}{l}3 \\
(5)\end{array}$ & $\begin{array}{l}0 \\
(0)\end{array}$ & 56 \\
\hline
\end{tabular}

Berdasarkan tabel 5 diatas menunjukkan bahwa rata-rata pengkajian penalaran deduktif dan penalaran dalam matematika berada pada kategori tinggi. Hal ini ditunjukan dari hasil persentase mahasiswa dalam berkomitmen sebesar 59\% berada pada kategori tinggi. Sedangkan persentase mahasiswa dalam bertanggung jawab sebesar $61 \%$ berada pada kategorti tinggi. 
Tabel 6. Berlatih menggunakan penalaran deduktif dan induktif dalam pembelajaran matematika

\begin{tabular}{|c|c|c|c|c|c|c|}
\hline \multirow{2}{*}{ Indikator } & \multicolumn{5}{|c|}{$\sum$ dan \% } & \multirow{2}{*}{ Jumlah } \\
\hline & 5 & 4 & 3 & 2 & 1 & \\
\hline Kesulitan pembentukan konsep & $\begin{array}{l}0 \\
(0)\end{array}$ & $\begin{array}{l}17 \\
(30)\end{array}$ & $\begin{array}{l}34 \\
(61)\end{array}$ & $\begin{array}{l}5 \\
(9)\end{array}$ & $\begin{array}{l}0 \\
(0)\end{array}$ & 56 \\
\hline Kesalahan pembentukan konsep & $\begin{array}{l}0 \\
(0) \\
\end{array}$ & $\begin{array}{l}20 \\
(36)\end{array}$ & $\begin{array}{l}30 \\
(54)\end{array}$ & $\begin{array}{l}6 \\
(11)\end{array}$ & $\begin{array}{l}0 \\
(0)\end{array}$ & 56 \\
\hline Menkaji pengetahuan secara deduktif dan induktif & $\begin{array}{l}3 \\
(5)\end{array}$ & $\begin{array}{l}21 \\
(38)\end{array}$ & $\begin{array}{l}28 \\
(50)\end{array}$ & $\begin{array}{l}4 \\
(7)\end{array}$ & $\begin{array}{l}0 \\
(0)\end{array}$ & 56 \\
\hline Menggunakan pengetahuan secara deduktif & $\begin{array}{l}1 \\
(2)\end{array}$ & $\begin{array}{l}31 \\
(55) \\
\end{array}$ & $\begin{array}{l}23 \\
(41) \\
\end{array}$ & $\begin{array}{l}1 \\
(2)\end{array}$ & $\begin{array}{l}0 \\
(0) \\
\end{array}$ & 56 \\
\hline Menggunakan pengetahuan secara induktif & $\begin{array}{l}3 \\
(5)\end{array}$ & $\begin{array}{l}23 \\
(41)\end{array}$ & $\begin{array}{l}27 \\
(48)\end{array}$ & $\begin{array}{l}3 \\
(5) \\
\end{array}$ & $\begin{array}{l}0 \\
(0) \\
\end{array}$ & 56 \\
\hline
\end{tabular}

Berdasarkan tabel 6 diatas, menunjukan bahwa rata-rata penggunaan penalaran deduktif dan induktif dlam pembelajaran matematika berada pada kategori tinggi. Hal ini ditunjukkan dari hasil persentase kesulitan mahasiswa dalam pembentukan konsep sebesar $61 \%$ dengan kategori cukup tinggi. Persentase kesalahan mahasiswa dalam pembentukan konsep sebesar 54\% dengan kategori cukup tinggi. Persentase mahasiswa dalam mengkaji pengetahuan secara deduktif dan induktif sebesar $50 \%$ berada pada kategori cukup tinggi. Persentase mahasiswa menggunakan pengetahuan secara deduktif sebesar $55 \%$ berada pada kategori tinggi. Persentase mahasiswa dalam menggunakan pengetahuan secraa induktif sebesar $48 \%$ berada pada kategori cukup tinggi.

Tabel 7. Penerapan Matematika dalam kehidupan sehari-hari secara kreatif

\begin{tabular}{|c|c|c|c|c|c|c|}
\hline \multirow{2}{*}{ Indikator } & \multicolumn{5}{|c|}{$\sum$ dan \% } & \multirow{2}{*}{ Jumlah } \\
\hline & 5 & 4 & 3 & 2 & 1 & \\
\hline Penerapan pemecahan masalah & $\begin{array}{l}0 \\
(0)\end{array}$ & $\begin{array}{l}25 \\
(45)\end{array}$ & $\begin{array}{l}27 \\
(48)\end{array}$ & $\begin{array}{l}4 \\
(7)\end{array}$ & $\begin{array}{l}0 \\
(0)\end{array}$ & 56 \\
\hline Membiasakan diri dalam memecahkan masalah & $\begin{array}{l}1 \\
(2)\end{array}$ & $\begin{array}{l}25 \\
(45)\end{array}$ & $\begin{array}{l}25 \\
(45)\end{array}$ & $\begin{array}{l}5 \\
(45)\end{array}$ & $\begin{array}{l}0 \\
(9)\end{array}$ & 56 \\
\hline Kreatif dalam pemecahan masalah & $\begin{array}{l}2 \\
\text { (4) }\end{array}$ & $\begin{array}{l}19 \\
(34)\end{array}$ & $\begin{array}{l}31 \\
(55)\end{array}$ & $\begin{array}{l}4 \\
(7)\end{array}$ & $\begin{array}{l}0 \\
(0)\end{array}$ & 56 \\
\hline
\end{tabular}

Berdasarkan tabel 7 diatas, menunjukkan bahwa rata-rata pemecahan masalah matematika dan penerapan alam kehidupan sehari-hari berada pada kategori cukup. Hal ini ditunjukkan dari hasil penerapan mahasiswa dalam pemecahan masalah sebesar $48 \%$ dengan kategori cukup. Persentase mahasiswa dalam membiasakan diri dalam memecahkan masalah matematika sebesar $45 \%$ berada pada kategori tinggi. Sedangkan persentase mahasiswa dalam menumbuhkan kreatifitas dalam memecahkan masalah matematika sebesar 55\% berada pada kategori cukup. Hasil penelitian ini relevan dengan penelitian yang sebelumnya dilakukan oleh Prasetyo \& Purnomo (2016) menyatakan bahwa kemampuan penguasaan matematika khususnya pemecahan masalah masih belum optimal, hal ini dikarenakan mahasiswa dalam pembelajaran matematika bersifat konvensional dimana kegiatan pembelajaran dimulai dengan teori, contoh soal dan dilanjutkan dengan pengerjaan soal. Demikian juga dengan penelitian yang dilakukan oleh Purnomo \& Prasetyo (2016) yang menyatakan bahwa mahasiswa cenderung menghafal metode-metode yang banyak dipelajari pada mata kuliah matematika. 
Stusi Penguasaan Matematika dan Bahasa Inggris Mahasiswa Program Studi Pendidikan Guru Sekolah Dasar (PGSD) (Wahyu Pramudita, Indri Anugraheni)

\section{Hasil Penguasaan Bahasa Inggris}

Pentingnya penguasaan Bahasa Inggris dan keterkaitan keilmuan ini terhadap bidang keilmuan lain sangat signifikan. Profisiensi Bahasa Inggris sangat diperlukan terutama dalam hal pemetaan dalam mencapai tujuan pembelajaran. Dalam suatu proses pembelajaran, pemetaan kemampuan dapat memberikan gambaran atau hubungan langsung terhadap perencaan program dan tujuan perencanaan program tersebut secara holistik (Depdiknas, 2009). Sugeng, Suhaini, dan Suharto (2012) dalam penelitian yang dilakukan mengungkapkan bahwa dalam tujuan komunikasi bahasa, tes profisiensi dapat mengungkap atau menafsirkan fungsi dan ujaran bahasa peserta tes. Dalam fungsi ini, pengambil keputusan mendapatkan informasi seberapa baik peserta tes dapat menggunakan bahasa untuk bertutur, lisan dan tulisan. Dalam tujuan perencanaan, tes profisiensi dapat mengungkapkan karakter peserta tes sebagai masukan dalam suatu program. Dalam fungsi ini, pengambil keputusan menyesuaikan perlakuan (treatment) dalam suatu program dengan karakteristik peserta tes. Hal lain terkait dengan penelitian ini menyatakan bahwa tingkat penguasaan Bahasa Inggris yang baik berdampak signifikan terhadap hasil belajar mahasiswa. Hal ini memberikan korelasi positif bahwa penguasaan Bahasa Inggris berdampak pada penguasaan bidang keilmuan lain (Simner, et al., 2000: 43). Dalam penelitian ini penguasaan Bahasa Inggris mahasiswa dibagi dalam 2 indikator; kemampuan dasar Bahasa Inggris dan kemampuan memanfaatkan berbagai referensi dalam bahasa Inggris. Berikut adalah hasil masing-masing indikator tersebut.

Tabel 8. Kemampuan dasar Bahasa Inggris

\begin{tabular}{|c|c|c|c|c|c|c|}
\hline \multirow{2}{*}{ Indikator } & \multicolumn{5}{|c|}{$\sum$ dan $\%$} & \multirow{2}{*}{ Jumlah } \\
\hline & 5 & 4 & 3 & 2 & 1 & \\
\hline Mampu membuat kalimat & $\begin{array}{l}1 \\
\text { (2) }\end{array}$ & $\begin{array}{l}19 \\
(34)\end{array}$ & $\begin{array}{l}32 \\
(57)\end{array}$ & $\begin{array}{l}4 \\
\text { (7) }\end{array}$ & $\begin{array}{l}0 \\
(0)\end{array}$ & 56 \\
\hline Mengidentifikasi kalimat & $\begin{array}{l}2 \\
(4)\end{array}$ & $\begin{array}{l}11 \\
(20)\end{array}$ & $\begin{array}{l}32 \\
(57)\end{array}$ & $\begin{array}{l}11 \\
(20)\end{array}$ & $\begin{array}{l}0 \\
(0)\end{array}$ & 56 \\
\hline Memperbaiki kalimat yang salah & $\begin{array}{l}2 \\
\text { (4) }\end{array}$ & $\begin{array}{l}14 \\
(25)\end{array}$ & $\begin{array}{l}36 \\
(64)\end{array}$ & $\begin{array}{l}4 \\
(7)\end{array}$ & $\begin{array}{l}0 \\
(0)\end{array}$ & 56 \\
\hline Menjawab pertanyaan bacaan secara lisan & $\begin{array}{l}1 \\
\text { (2) }\end{array}$ & $\begin{array}{l}12 \\
(21)\end{array}$ & $\begin{array}{l}37 \\
(66)\end{array}$ & $\begin{array}{l}6 \\
(11)\end{array}$ & $\begin{array}{l}0 \\
(0)\end{array}$ & 56 \\
\hline Menjawab pertanyaan bacaan secara tertulis & $\begin{array}{l}1 \\
(2)\end{array}$ & $\begin{array}{l}20 \\
(36)\end{array}$ & $\begin{array}{l}31 \\
(55)\end{array}$ & $\begin{array}{l}4 \\
(7)\end{array}$ & $\begin{array}{l}0 \\
(0)\end{array}$ & 56 \\
\hline Memberikan feedback dalam bahasa Inggris & $\begin{array}{l}1 \\
(2)\end{array}$ & $\begin{array}{l}8 \\
(14)\end{array}$ & $\begin{array}{l}39 \\
(70)\end{array}$ & $\begin{array}{l}8 \\
(14)\end{array}$ & $\begin{array}{l}0 \\
(0)\end{array}$ & 56 \\
\hline Menerapkan dan mengembangkan kalimat & $\begin{array}{l}2 \\
(4)\end{array}$ & $\begin{array}{l}10 \\
(18)\end{array}$ & $\begin{array}{l}37 \\
(66)\end{array}$ & $\begin{array}{l}7 \\
(13)\end{array}$ & $\begin{array}{l}0 \\
(0)\end{array}$ & 56 \\
\hline Menghasilkan teks tulisan sederhana & $\begin{array}{l}0 \\
(0)\end{array}$ & $\begin{array}{l}21 \\
(38)\end{array}$ & $\begin{array}{l}29 \\
(52)\end{array}$ & $\begin{array}{l}6 \\
(11)\end{array}$ & $\begin{array}{l}0 \\
(0)\end{array}$ & 56 \\
\hline
\end{tabular}

Berpijak dari kemampuan membaca mahasiswa, tingkat penguasaan keterampilan menulis tergolong bervariasi dengan distribusi indikator sebagai berikut. Kemampuan membuat kalimat tergolong cukup 57\%. Kemampuan ini tergolong mendasar bagi calon guru SD terutama dalam 
memberikan respon tertulis secara sederhana. Kemampuan membuat kalimat ini didukung dengan kemampuan mengidentifikasi kalimat yang tergolong cukup (57\%). Kemampuan memproduksi kalimat sederhana dan mengidentifikasi kalimat secara baik dan benar mendukung kemampuan mahasiswa dalam memperbaiki kalimat yang salah (64\%) dan, dari kesalahan itu, dapat memberikan konsep pengembangan kalimat (66\%) dalam meningkatkan kemampuan memproduksi teks tulis sederhana (52\%). Kemampuan dasar Bahasa Inggris mahasiswa ini tergolong cukup. Tingkatan cukup ini memang sudah dianggap memenuhi syarat minimal bagi mahasiswa (non-English department) untuk lulus dan sekaligus bekal dasar untuk berkomunikasi, tulis atau lisan. Hasil ini berbanding lurus dengan penelitian Sofendi (2010) terhadap 513 mahasiswa FKIP Unsri (kecuali prodi Bahasa Inggris) terkait pemetaan penguasaan Bahasa Inggris mahasiswa. Dengan kategori pre-elementary ini mahasiswa sudah memiliki bekal awal untuk mampu menggunakan prasa yang diingat dalam kondisi darurat, dapat membuat pertanyaan dan pernyataan singkat, dan memiliki kemampuan komunikasi terbatas dan sering melakukan pengulangan. Namun seiring dengan rentang waktu perkuliahan dan interaksi akademis yang terbangun, kemampuan mahasiswa diharapkan dapat meningkat.

Tabel 9. Kemampuan memanfaatkan berbagai referensi dalam bahasa Inggris

\begin{tabular}{|c|c|c|c|c|c|c|}
\hline \multirow{2}{*}{ Indikator } & \multicolumn{5}{|c|}{$\sum$ dan \% } & \multirow{2}{*}{ Jumlah } \\
\hline & 5 & 4 & 3 & 2 & 1 & \\
\hline Mengakses refrensi pembelajaran & $\begin{array}{l}1 \\
\text { (2) }\end{array}$ & $\begin{array}{l}15 \\
(27)\end{array}$ & $\begin{array}{l}35 \\
(63)\end{array}$ & $\begin{array}{l}5 \\
(9)\end{array}$ & $\begin{array}{l}0 \\
(0)\end{array}$ & 56 \\
\hline Memahami komunikasi digital & $\begin{array}{l}0 \\
(0)\end{array}$ & $\begin{array}{l}16 \\
(29)\end{array}$ & $\begin{array}{l}36 \\
(64) \\
\end{array}$ & $\begin{array}{l}4 \\
(7)\end{array}$ & $\begin{array}{l}0 \\
(0) \\
\end{array}$ & 56 \\
\hline Membaca teks bahasa Inggris & $\begin{array}{l}0 \\
(0)\end{array}$ & $\begin{array}{l}18 \\
(32)\end{array}$ & $\begin{array}{l}31 \\
(55)\end{array}$ & $\begin{array}{l}7 \\
(13)\end{array}$ & $\begin{array}{l}0 \\
(0)\end{array}$ & 56 \\
\hline Menulis Citation (Catatan kecil) & $\begin{array}{l}2 \\
(4)\end{array}$ & $\begin{array}{l}14 \\
(25)\end{array}$ & $\begin{array}{l}28 \\
(50) \\
\end{array}$ & $\begin{array}{l}12 \\
(21)\end{array}$ & $\begin{array}{l}0 \\
(0)\end{array}$ & 56 \\
\hline Memahami kosakata & $\begin{array}{l}3 \\
(5)\end{array}$ & $\begin{array}{l}17 \\
(30)\end{array}$ & $\begin{array}{l}32 \\
(57)\end{array}$ & $\begin{array}{l}4 \\
(7)\end{array}$ & $\begin{array}{l}0 \\
(0)\end{array}$ & 56 \\
\hline Memahami informasi rinci/ detail & $\begin{array}{l}1 \\
\text { (2) }\end{array}$ & $\begin{array}{l}15 \\
(27)\end{array}$ & $\begin{array}{l}34 \\
(61)\end{array}$ & $\begin{array}{l}6 \\
(11)\end{array}$ & $\begin{array}{l}0 \\
(0)\end{array}$ & 56 \\
\hline Memahami tujuan komunikasi & $\begin{array}{l}2 \\
\text { (4) }\end{array}$ & $\begin{array}{l}18 \\
(32)\end{array}$ & $\begin{array}{l}32 \\
(57)\end{array}$ & $\begin{array}{l}4 \\
(7)\end{array}$ & $\begin{array}{l}0 \\
(0)\end{array}$ & 56 \\
\hline Memahami pikiran utama paragraph dalam teks & $\begin{array}{l}0 \\
(0)\end{array}$ & $\begin{array}{l}15 \\
(27)\end{array}$ & $\begin{array}{l}36 \\
(64)\end{array}$ & $\begin{array}{l}5 \\
(9)\end{array}$ & $\begin{array}{l}0 \\
(0)\end{array}$ & 56 \\
\hline Memahami gaya bahasa teks & $\begin{array}{l}2 \\
\text { (4) }\end{array}$ & $\begin{array}{l}9 \\
(16)\end{array}$ & $\begin{array}{l}39 \\
(70)\end{array}$ & $\begin{array}{l}5 \\
(9)\end{array}$ & $\begin{array}{l}1 \\
(2)\end{array}$ & 56 \\
\hline Memahami gaya penulisan teks & $\begin{array}{l}1 \\
\text { (2) }\end{array}$ & $\begin{array}{l}10 \\
(18)\end{array}$ & $\begin{array}{l}36 \\
(64)\end{array}$ & $\begin{array}{l}9 \\
(16)\end{array}$ & $\begin{array}{l}0 \\
(0)\end{array}$ & 56 \\
\hline Memahami informasi tersirat & $\begin{array}{l}2 \\
(4)\end{array}$ & $\begin{array}{l}13 \\
(23)\end{array}$ & $\begin{array}{l}37 \\
(66)\end{array}$ & $\begin{array}{l}4 \\
(7)\end{array}$ & $\begin{array}{l}0 \\
(0)\end{array}$ & 56 \\
\hline
\end{tabular}

Kemampuan membaca sebagai pondasi awal dalam rangka meningkatkan pemahaman bacaan mahasiswa tergolong cukup. Kemampuan mengakses referensi ini $(63 \%)$ berbanding lurus dengan kemampuan memahami bacaan/sarana komunikasi digital (64\%) yang juga mendukung kemampuan membaca teks Bahasa Inggris secara komprehensif (55\%). Kemampuan membaca komprehensif mahasiswa PGSD, juga didukung oleh kemampuan memahami kosakata (57\%). Kosakata merupakan kunci utama dalam memahami arah, tujuan, dan isi dari referensi bacaan. Dengan tingkat kemampuan menguasai kosakata yang tergolong cukup, menjadikan bekal mahasiswa dalam memahami informasi 
Stusi Penguasaan Matematika dan Bahasa Inggris Mahasiswa Program Studi Pendidikan Guru Sekolah Dasar (PGSD) (Wahyu Pramudita, Indri Anugraheni)

rinci/detail juga tergolong cukup $(61 \%)$ sehingga kemampuan memahami tujuan komunikatif dari suatu teks pun dapat dipahami dengan cukup (57\%).

Kemampuan dalam memahami tujuan komunikatif teks, berdampak pada kemampuan memahami pikiran utama dari suatu paragraf (64\%), termasuk di dalamnya kemampuan menguasai gaya bahasa $(70 \%)$, dan gaya penulisan $(64 \%)$ dalam memahami informasi tersirat (66\%). Dalam mendukung respon terhadap pemahaman bacaan ini, mahasiwa juga dapat memberikan respon terkait referensi bacaan ataupun feedback dalam bahasa inggris (70\%). Pemahaman referensi bacaan yang tidak secara menyeluruh dikuasai sangat berdampak pada kompetensi mahasiswa dalam menguasai bidang pekerjaannya secara kontekstual. Pentingnya pemahaman referensi bacaan dalam text Bahasa Inggris ini juga berbanding lurus dengan penelitian Firdaus, Ginanjar, Rizkiyana, Purnamasari, Muliati (2012) yang menekankan pada pengaruh Bahasa terhadap "student's intention to learn", variabel "perceived ease of use (PEU)". Hal ini disebabkan oleh pendapat sebagian besar mahasiswa yang mengikuti perkuliahan SAP ERP HCM ini mengeluhkan sulitnya memahami beberapa perintah yang ada di dalam user interface SAP dikarenakan tampilan dan aturannya sangat berbeda ditambah dengan lemahnya penguasaan bahasa Inggris mahasiswa.

\section{SIMPULAN DAN SARAN}

\section{Simpulan}

Dari hasil penelitian ini, maka dapat disimpulkan sebagai berikut: Rata-rata hasil kemampuan matematika mahasiswa PGSD berada pada kategori baik dan kemampuan Bahasa Inggris mahasiswa PGSD berada pada kategori cukup.

\section{Saran}

Adapun saran bagi pengembangan kedua keilmuan ini adalah Perlunya meningkatkan penguasaan pengetahuan konseptual dan prosedural serta keterkaitan dalam bidang aritmatika, aljabar, geometri, trigonometri, pengukuran, statistika dan logika matematika, Meningkatkan penguasaan pengetahuan menggunakan matematisasi horizontal dan vertical untuk menyelesaikan masalah, memberikan permasalah-permasalah Matematika dalam kehidupan sehari-hari yang mampu menumbuhkan kreatifitas mahasiswa, perlunya perhatian khusus (perancangan, implementasi, dan evaluasi) pada kemampuan Bahasa Inggris mahasiswa PGSD agar dapat meningkatkan kemampuan Bahasa Inggris dan memanfaatkan berbagai sumber dalam Bahasa Inggris untuk berbagai keperluan.

\section{DAFTAR PUSTAKA}

Ahmad, Susanto. 2013. Teori belajar dan pembelajaran di sekolah dasar. Jakarta: Kencana Prenada Media Group.

Anthony, L. 1997. English for specific purposes: what does it mean? why isit different?. On-CUE Journal, 5(3): 9-10.

Asturkmen, Helen. 1998. Refining procesure: A need analysis project at Kuwait University. http://exchanges.state.gov/forum/vols/vol36/no4/special_ret_102 ( Desember, 2014)

Ali, H. Muhamad. 2002. Guru dalam proses belajar mengajar. Bandung: Sinar Baru Algensindo Offset. 
Badan Penelitian dan Pengembangan Pendidikan Nasional. (2000). Laporan eksekutif beberapa permasalahan pendidikan. Jakarta: Balitbang Diknas.

Brant, C. 2009. The case for reflexivity in developing ESL students' academic communication skills. International Journal of Arts and Sciences 3(5): 1 - 18

Bertens, K. 2002. Filsafat barat kontemporer: Inggris-Jerman. Jakarta: PT Gramedia Pustaka Utama

Budayanti, I. 2012. Gambaran kompetensi guru kelas SD di Jakarta dan Tangerang. Jurnal Perkotaan, 4 (1):11-27

Carter, J.S. 2007. Mathematics. http://www.polimetrical. eu/site/?p=30. University of South Alabama, USA. (November 2014)

Coleman, H. 1997. Undergraduate ELT: Where have we been and where are we going? In Coleman, H., Soedrajat, T.M. \& Westaway, G. (eds.), Teaching English to University Undergraduates in the Indonesian Context: Issues and Developments, 26-42. Leeds: University of Leeds, School of Education \& Bandung: Institut Teknologi Bandung.

Departemen Pendidikan Nasional. 2002. Standar kompetensi guru kelas SD-MI program pendidikan D-II PGSD. Jakarta: Proyek Peningkatan Manajemen Pendidikan Tinggi Ditjen Dikti.

Departemen Pendidikan Nasional. 2006. Kurikulum tingkat satuan pendidikan (KTSP). Jakarta: Departemen Pendidikan Nasional

Departemen Pendidikan Nasional. 2009. Laporan Program Rintisan Uji Kompetensi Bahasa Inggris (Test of English Proficiency, TOEP) untuk Peserta Didik di SMA. Jakarta: Depdiknas, Direktorat Jenderal Manajemen Pendidikan Dasar dan Menengah

Ernest, Paul. 1991. The Philosophy of Mathematics Education. Bristol: The Falmer Press. http://plato.standford.edu/fundraising

Firdaus Oktri, Gin Gin Ginanjar, Trisye Rizkiyana, Dewi Purnamasari, Fitria Muliati. 2012. Model efektivitas pembelajaran SAP ERP HCM pada program studi S1 manajemen Universitas Widyatama. In Universitas Widyatama (Eds.), Perkembangan peran akuntansi dalam bisnis yang profesional (pp. 1397-1405). Bandung: Utama Press.

Hamalik, O. 2002. Pendidikan guru: berdasarkan pendekatan kompetensi. Jakarta: PT Bumi Aksara.

Hamzah B, Uno. 2009. Model pembelajaran (menciptakan proses belajar mengajar yang kreatif dan efektif), Jakarta: Bumi Aksara.

Harry F., and T. Burhanudin. 2008. The future of schooling in Indonesia. Journal of International Cooperation in Education, 11 (1): 71-84.

Hudoyo .1988. Pengembangan kurikulum matematika dan pelaksanaannya di depan kelas. Surabaya: Usaha Nasional

Khoirunisa, Rifa. 2012. Pengaruh kemampuan pemahaman istilah Bahasa Inggris dan operasi dasar matematika terhadap kemampuan belajar siswa pada mata pelajaran teknologi informasi dan komunikasi kelas XI di SMAN 2 Wates. Skripsi. Program Sarjana Teknik Informatika Universitas Negeri Yogyakarta. Yogyakarta.

Majelis Pendidikan Kejuruan Nasional, 1998. Acuan penyusunan standar kompetensi. Jakarta: MPKN.

Marjito. 2007. An analysis of syllabus and material and their relevance to the students' needs: acase study of a higher education of computer science. Unpublished thesis, Indonesian University of Education. 
Stusi Penguasaan Matematika dan Bahasa Inggris Mahasiswa Program Studi Pendidikan Guru

Sekolah Dasar (PGSD) (Wahyu Pramudita, Indri Anugraheni)

Marwan, A. 2009. ESP teaching challenges in an Indonesian vocational higher institution. The English Teacher Journal, 38: 1-12.

Mulyasa, E. 2005. Menjadi guru profesional. Menciptakan pembelajaran kreatif dan menyenangkan. Bandung: Remaja Rosdakarya.

Nurkalam, A. Ghozali. 1998. The existence of english for specific purposes (ESP) as an approach of the teaching of english. Wawasan tri dharma No. 8, Kopertis Wilayah IV.

Puspitasari, I. 2013. English For Computer Science: Sebuah Analisis Kebutuhan Bahasa Inggris Pada Mahasiswa Teknik Informatika. EJurnal Pro Bisnis, 6(1): 20-37

Prasetyo, Tony \&Andy Purnomo, E. 2016. Pengembangan Perangkat Pembelajaran dengan model ideal problem solving berbasis maple matakuliah metode numerik. the $4^{\text {th }}$ URECOL 2016. LPPM Stikes Muhammadiyah Pekajangan Pekalongan: 442-450

Rabbini. 2000. An Introduction to Syllabus Design and Evaluation. TESL Journal. 8 (5). http//iteslj.org/ (November, 2014).

Ruseffendi, E.T. 1988. Pengajaran matematika modern dan masa kini untuk guru dan SPG, Bandung: Tarsito.

Safnil. 1997. English for non-english department students of Bengkulu University: Problems and possible solution in teaching English to university undergraduates in the Indonesian context: issue and developments (pp.69-73). ITB press and University of Leeds, GB.

Slameto. 2003. Belajar dan faktor-faktor yang mempengaruhinya. Jakarta: PT Rineka Cipta.

Sofendi. 2010. Penguasaan Bahasa Inggris fakultas keguruan dan ilmu pendidikan Universitas Sriwijaya.Mengembangkan pembelajaran bahasa dan sastra yang aktif, inovatif, kreatif, efektif, menyenangkan, dan mengasyikkan. Universitas Sriwijaya (Eds.). Palembang: FKIP.

Sukmadinata, Nana Syaodih. 2009. Metode penelitian pendidikan. Bandung: Rosdakarya.

Sugeng, Suhaini, dan Suharto (2012). Penguasaan Bahasa Inggris mahasiswa baru UNY TA 2005/2006-2009-2010 pada kriteria TOEFL-LIKE. Jurnal Literia 11(2): 189-203

Suyitno, Hardi. 2008. Hubungan antara bahasa dengan logika dan matematika menurut pemikiran Wittgenstein. Humaniora; Journal of Culture, Literature, and Linguistics, 20 (1): 26-37

Suyono dan Hariyanto. 2012. Belajar dan pembelajaran -teori dan konsep dasar. Bandung: PT Remaja Rosdakarya Mack J

Sysoyev Parvel V. 2000. Developing an English for specific purposes course using a learner centered approach: Cambridge: Harvard University Press http://iteslj.org/Techniques (Desember, 2014).

Wittgenstein, L. 1951. Tractacus logico philosophicus. London: Routledge \& Kegan Paul Ltd. 